\title{
The Development of Financial Markets in Africa: Trends, Challenges and Prospects
}

\author{
Misheck Mutize, Ejigayhu Tefera, McBride Nkhalamba \\ University of Cape Town, South Africa \\ mmutize@gmail.com, Mtzmis001@gsb.uct.ac.za
}

\begin{abstract}
This paper explores trends and challenges in the development of African financial markets over the past two decades. Access to capital is essential for government to finance its budget and the performance of government policies is in part evaluated through how financial asset prices respond to the policy choices. Erratic security issuance, thin trading, low turnover ratios and lack of market depth has characterised African financial markets as inefficient. Applying a descriptive research model on key data from international think tanks to observe the behaviour of financial markets data in African countries, the study finds that African financial markets still face the traditional challenge of lack of market depth relative to other regions in other continents due to their limit size and very low market capitalisation. This is a key factor holding back the ability of investors to exploit expansion opportunities. This paper recommends that, part of the solution to challenges faced by African financial markets is for governments to assist in set-up electronic trading platforms, improve trading and settlement infrastructure.
\end{abstract}

Keywords: Development; African financial market; bonds; stock exchange; government policy.

\section{Introduction}

Historically, the majority of fiscal support for African governments has been heavily dependent on Foreign Direct Investments (FDIs), international donor support and multilateral loans from Bretton Wood institutions. Recent trends in developmental funding support shows that development partners and traditional financiers are scaling down on their volume of funding assistance (Organisation for Economic Cooperation and Development (OECD), 2018). This dynamic has inevitably forced African countries to diversify, their funding sources by developing capacity in their local financial markets and integrating into global financial markets to access global capital through sovereign bond issuance. According to OECD (2015), neither African governments nor their private sector have sufficient capacity to fully fund their infrastructure projects and other balance sheet activities. Therefore, this has driven the strong appetite for the development of financial markets in Africa to support the various infrastructural projects that needs funding. The Africa Capital Markets Report (2017) present data showing that the African continent requires more than US\$25 billion per annum for infrastructure projects, while it can only mobilise a maximum of US\$10 billion from local resources. Furthermore, the low yields of near zero in developed economies have pushed international investors to shift their focus to developing markets for high yields averaging 6 per cent driven by high economic growth prospects.

Thus placing African financial markets on the spotlight. This paper makes a scientific analysis of the challenges faced by financial markets in Africa, examining their developmental trend and their future prospects. Some to the key challenges identified and analysed are; thin trading, low turnover ratios and lack of market depth, which has characterised African financial markets as inefficient. The challenges have a direct impact on bond yields and interest rates, which literature debates on whether they are overpriced or depressed. Data presented in the Africa Capital Markets Watch 2018 Report shows a strong investor appetite for African financial assets due to high yields. On the contrary, other literature argue that political administrations are borrowing irresponsibly without evaluating the real cost of financial market borrowings. However, other literature asserts that the level of local financial markets development is a key indicator of the capacity of political administrations to mobilize local resources. Thus, this paper makes recommendations for African countries to address the challenges faced by their financial markets. The study proceeds as follows. Section 2 analysis the literature on financial markets importance and characteristics, followed by the methodology and data description in Section 3. The results and discussion is presented in Section 4. Then after, the study then concludes with recommendations on enhancing financial markets in Africa in Section 5. 


\section{Literature Review}

The relationship between financial markets development and the policies adopted by political administrations are closely correlated (Ferrara and Sattler, 2018). Ferrara and Sattler (2018) provide evidence that, performance of a political administration as a policymaker is evaluated through how financial asset prices respond to their policy choices and government activities. In Fundamental Analysis, political events, social events, economic announcements, government policy change and company earnings are important in the determination of prices of financial assets on daily basis (Bernhard and Leblang, 2006). Business confidence and market sentiments are products of the optimism created by the policies of political administration about future macroeconomic prospects, a key component of Fundamental Analysis. Newell (2019) highlights that, it is the expectations for a future positive economic growth that drives investors to commit their capital for future returns, creating demand which in turn push the value of financial assets up. Bad policy choices typically drives financial asset prices down, whilst inconsistent policies increase the volatility of asset prices causing uncertainties around the realization of the expected return.

In such an environment, investors prefer to commit their capital for short term periods for fear of losses and demand high interest rates in return. These policy choices have a direct implication on government's ability to raise capital through financial markets as well as debt servicing costs. On the other hand, the scepticism of investors in committing their funds on long-term capital expenditures to create jobs, supports household expenditure and generate economic profits, also have negative implications on unemployment, inflation and GDP (Ivashina and Lerner, 2019). Hence, it is political choices that have an ultimate influence on the behaviour of investors and performance of policies through policy. These studies show that, for political administrations, access to capital is essential for government to finance its budget and support its policy implementation plans. Thus, financial markets present an open opportunity for governments to widen their funding options available to finance infrastructure, fund budget deficit and support the private sector away from the traditional funding models such as multilateral borrowing. It is easy for the government and other reputable organisations to raise funds through financial markets at little cost (Hrnjic et al., 2019).

On the other hand, financial markets penalise governments and other institutions with track records of corruption scandals, lack of accountability and unstable strategic plans (Evans, 2019). For example, in 2017, South Africa's logistics government-owned enterprise, Transnet raised only R55 million far below its targeted R600 million during its failed bond auctions because investors were sceptical of the maladministration in state-owned enterprises under the country's former President Jacob Zuma (Mutize and Gossel, 2017). The success of any government policies is evaluated by the performance of the economy, a high economic growth signify a successful policy implementation (Karlsson and Tavassoli, 2019). The World Economic Forum (2018) report shows that the development of financial markets is significantly correlated to economic growth. A moderately liquid and efficient financial market is a key component in supporting a healthy economy. According to Fama (1976), without efficient financial markets, it is impossible to connect surplus capital to deficit units that needs investment capital. They are essential in the intermediation between borrowers and lenders as well as supporting institutions in the provision of goods and services.

\section{Methodology and Data Description}

This study applies a descriptive analysis, observing and describing the behavior of African financial markets data to reflect on their challenges and prospects. Some of the key data utilized was obtained from the Official Monetary and Financial Institutions Forum (OMFIF) report of 2017 and 2018, an independent think tank for central banking, economic policy and public investment. Another data source was International Centre for Tax and Development (ICTD) report (2019), United Nations Conference on Trade and Development (UNCTAD) report (2018), Bank for International Settlements (BIS) annual report (2017), Africa Financial Markets Initiative (AFMI) annual conference report (2018), The Africa Capital Market Watch reports (2017 \& 2018), African Securities Exchange Association (ASEA) annual report (2017, 2018 \& 2019) and Centre for Affordable Housing Finance in Africa (CAHFA) (2017). Stock exchange data was obtained from respective African stock exchanges websites to verify some of the data in think tanks' annual reports. 


\section{Results and Discussion}

The study find that one of the key traditional challenge faced by African financial markets is lack of market depth, compared to other Latin America and Asian markets, due to their limited size and very low market capitalisation. It is found that, this is a key factor holding back the ability of investors to exploit expansion opportunities. Despite the positive developments registered in recent years, Africa's financial markets are still illiquid with thin turnover ratios of less than 1 per cent in approximately a quarter of the financial markets. Africa's financial markets share of the global equity turnover is less than 0.05 per cent (Official Monetary and Financial Institutions Forum (OMFIF), 2017). The major causes of liquidity challenges are; fewer number listed companies, thin secondary market trading and long settlement periods. Besides South Africa, the majority of African financial markets have less than 10 listed securities and trade for less than 3 days out of the normal 5 trading days per week. The Algiers Stock Exchange trades for only 1 day in a week, Uganda Securities Exchange trades for 2 days in a week, whilst the Dar es Salaam Stock Exchange and the Bourse Régionale des Valeurs Mobilières trades for 3 days in a week. Another finding is that, it is lack of liquidity that is discouraging companies and securities to list on African exchanges as the markets have no capacity to raise the capital they need.

Especially African mining companies that constantly need huge capital market liquidity support and often end up list on global exchanges. Of the 1318 mining companies listed on Toronto Stock Exchange, 118 of them are African mining companies. In addition to the low liquidity, the high exchange listing fees, legal fees and other costs of making company trading information accessible to shareholders, together makes the listing exercise unviable. The structure of investors participating in financial markets also impedes trading activity as many of the financial instruments tend to be held by large institutions such as pension funds that buy-and-hold to maturity. Therefore, there are difficulties in supporting Africa's financial markets trading systems, perform market analysis and brokerage services as liquidity and trade volume is very low. This has created huge gaps between buy and sell orders, ultimately eroding public self-assurance within the integrity of African financial markets. Consequences also show that the gradual facts production has hampered efficiency, trading activity and turnover, rendering economic integration with worldwide markets hard as the majority of African monetary markets do not have relevant depository systems. Such bottlenecks have induced inactivity in secondary markets of credit rated securities. The following Table 1 shows the turnover data for active financial markets in Africa.

Table 1: African Financial Market Indicators

\begin{tabular}{|c|c|c|c|c|}
\hline Country & $\begin{array}{l}\text { Market } \\
\text { capitalisation, } \\
\% \text { of GDP }\end{array}$ & $\begin{array}{l}\text { Total turnover of } \\
\text { equities, \% of } \\
\text { Market } \\
\text { capitalisation }\end{array}$ & $\begin{array}{l}\text { Total turnover in } \\
\text { bond market, \% } \\
\text { Bonds } \\
\text { outstanding }\end{array}$ & $\begin{array}{l}\text { Total sovereign and } \\
\text { corporate bonds } \\
\text { outstanding, listed on } \\
\text { exchanges, \$Billion }\end{array}$ \\
\hline South Africa & 358 & 41 & 970 & 195 \\
\hline Egypt & 11 & 54 & 23 & 39 \\
\hline Kenya & 28 & 8 & 48 & 9 \\
\hline Tanzania & 18 & 2 & 4 & 2 \\
\hline Morocco & 57 & 9 & 1 & 55 \\
\hline Mozambique & 9 & 0 & 4 & 0 \\
\hline Nigeria & 13 & 4 & 0 & 16 \\
\hline Ivory Coast & 35 & 4 & 4 & 5 \\
\hline Mauritius & 80 & 4 & 0 & 6 \\
\hline Seychelles & 10 & 2 & - & 0 \\
\hline Zambia & 32 & 0 & 15 & 2 \\
\hline Botswana & 269 & 1 & 5 & 1 \\
\hline
\end{tabular}




\begin{tabular}{lllll}
\hline Uganda & 25 & 1 & - & 2 \\
Ghana & 32 & 1 & 7 & 12 \\
Namibia & 24 & 1 & 0 & 12 \\
Rwanda & 40 & 1 & 2 & 0 \\
Ethiopia & - & - & - & - \\
\hline
\end{tabular}

Source: African Securities Exchanges Association, OMFIF analysis (2018)

This research observes that investment in infrastructure that support financial market development has not been prioritised in the majority of African countries. Evidence from government expenditure in other service sectors such as information communication technology infrastructure constitute more than 5\% of national budgets, whilst the expenditure in financial development infrastructure in virtually non-existent. In an average financial market in Africa, trading, clearing and settlement systems takes more than 30 days to complete a single transaction. According to the findings in this study, approximately 25 percent of the exchanges still operate manual systems compared to real-time transactions in developed markets. For instance, Malawi Stock Exchange and the Zimbabwe Stock Exchange takes 7 days to settle transaction accounts and more than 30 days to deliver share certificates. Cameroon's Douala Stock Exchange and Bolsa de Valores de Mozambique do not have central depository systems to hold proof of security ownership in the form of certificates or any uncertificated form in order that ownership can be easily transferred through a book access instead of the transfer of bodily certificates. The study further observed another key challenge in African financial markets, poor regulatory controls on foreign investments.

Except South Africa, African countries score below standard on the Official Monetary and Financial Institutions Forum (2017)'s foreign exchange index, reflecting its excessive capital controls, low respectable change price reporting standards, loss of harmonised domestic exchange price, and non-liquid interbank forex marketplace. Besides, South Africa, Egypt Stock Exchange and Namibian Stock Exchange, regulations in the majority of African exchanges require that private traders be both residents or at the least citizens to satisfy the documentation required to purchase financial assets on an exchange. The restrictive legislation prohibiting private investors was put in place to prevent illicit capital flows, curb tax evasions and money laundering. This effectively means private investors are generally prohibited from investing in a securities exchange unless they are physically residing inside the country. Moreover, the offerings of a traditional brokerage is in about 20 exchanges which have not yet been digitised. Within suited dates and in suitable capitalization, constitute a key criterion for well-functioning financial markets. African governments fail to provide for such situations because of strict forex controls, restricting unfastened waft of capital in and out of their jurisdictions, making it difficult for investor to move their capital out after divesting.

In line with the Global financial Fund (2018) economic Outlook report on Sub-Saharan Africa, the study find that a predicted 60 percent of the countries have controlled exchange rate policies. These policies do not allow their currencies to trade without much interference, rationing and blocking foreign currency repatriation of capital, causing great losses to foreign investors. There may be sluggish tempo within the adoption of global financial guidelines and reporting requirements which include worldwide financial reporting requirements and the Basel worldwide regulatory framework in African economic markets, has in addition stifling growth. International financial reporting requirements are supposed to enhance transparency and uniformity of financial statements among businesses across international locations. Another challenge to African financial markets is lack of transparency and availability of information published regularly and timely for the investment public to scrutinise. Relevant asset information is key to reducing screening costs and preventing adverse selection. Public availability of information on companies' audited financial statements, daily historical security prices, cautionary statements, in-depth analyst commentaries, company's business model, management and governance on exchanges' websites, public media and analyst statements is a desirable characteristic for efficient markets.

Besides the Egyptian, Johannesburg and Nigerian Exchanges, no African exchange neither operate an electronic security exchange system that convey real time security prices (Official Monetary and Financial Institutions Forum, 2017). With information asymmetries, brokers usually fail to execute orders and settle 
transactions as it takes too long before an investor makes a buy or sell decision, exacerbating the lack of active market participants and illiquid market. A single financial market transaction in Africa incur the following costs; commissions, brokerage fees, state settlement costs, investor protection levy, Value Added Tax (VAT), Securities Transfer Tax, administration fees and Capital Gains Tax. Brokerages charges are often five times lower in London compared to African markets where brokerage fees are above $2.5 \%$ (Standard Bank Stockbrokers, 2019). In addition, the tax charges represent about $3 \%$ of the transaction compared to less than $0.02 \%$ in other developed countries, a cost which buyers interpret as penalty for doing business in Africa. Rwanda, Mozambique, Seychelles and Egypt have the longest rebate intervals of more than 12 months, withholding tax of $15 \%$ on overseas buyers (which average $11 \%$ in 17 African countries). In addition, African countries have the highest market transaction-related taxes, because of a combination of low tax treaties and market incentives, excessive withholding, capital gains, other taxes. African markets are nevertheless in early levels of development and wishes a supportive tax environment which does no longer penalise economic marketplace transactions, alternatively ambitions to encourage them thru incentives and different fiscal measures. The size of bond market in each country is less than 10 per cent of country's GDP on average. The Africa Financial Markets Initiative (AFMI) annual coference report (2018) exhibit that the total outstanding amount of African bonds and bills rose to US\$ 413 billion in 2017, 13 per cent higher the 2016, with bonds made up 70 per cent of the amount. The report further shows that a total of US\$ 245 billion of treasury bonds and bills were issued in 2017, up 12 per cent compared to 2016. Of this, a total of US\$ 196 billion (80 per cent) were financial instruments with term to maturity of less than 1 year.

On the bond markets, US $\$ 19$ billion of financial instruments with terms of 1 to 5 years, US $\$ 12$ billion of bonds with term 5 to 10 years and US\$ 18 billion of bonds longer than 10 years. This data proves that introducing new financial instruments is on an upward trend. However, the tenure of the instruments is too short to allow meaningful capital investments from the proceeds of issuances. In line with the Africa Capital Market Watch report (2018), results show that only 8 countries have financial markets with debt capitalization of above US\$10 billion, whilst 19 countries have financial markets with debt capitalisation of below US $\$ 1$ billion. This shows that the volume of trades and the size of African markets is very small but there is however a huge appetite for African, financial instruments. Figure 1 below show the volume and value of corporate debt sold by African companies in foreign currency.

\section{Figure 1: African Foreign Currency Corporate Debt Volume and Value}

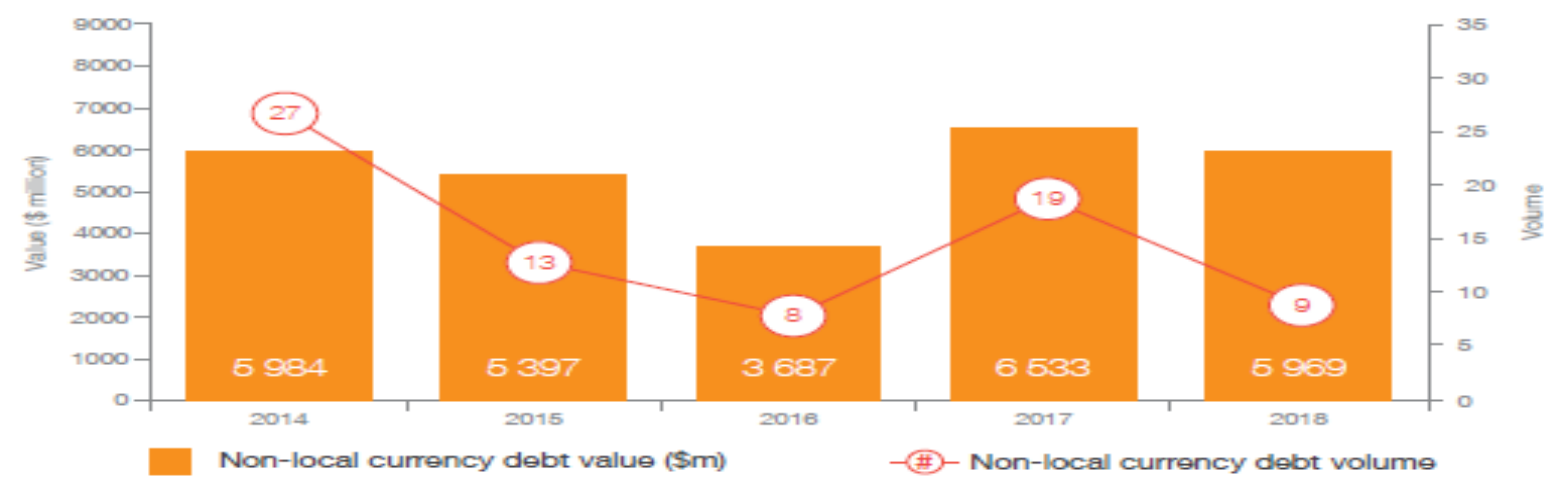

Source: Africa Capital Markets Report 2018

With significant positive stock market performance, Egyptian stock market has maintained its position as a best performer compared to other world markets since June 2013, according to Morgan Stanley, its cumulative stock index rising by 79 per cent in four years. Indicators of stock market development such as, number of listings, turnover ratio, total market capitalisation, capitalisation-to-GDP, volume of trading and value of trading. In 2018, Africa's largest stock exchanges, the JSE and NSE had some landmark transactions such as the US\$ 819.3 million in May 2018 from the dual listing on local and international exchanges. Figure below shows the trend of stock market activity in new stock issues - Initial Public Offers (IPO) - as well as further offers (FO). The following Figure 2 shows the trend of stock market activity. 
Figure 2: Trend of Stock Market Activity

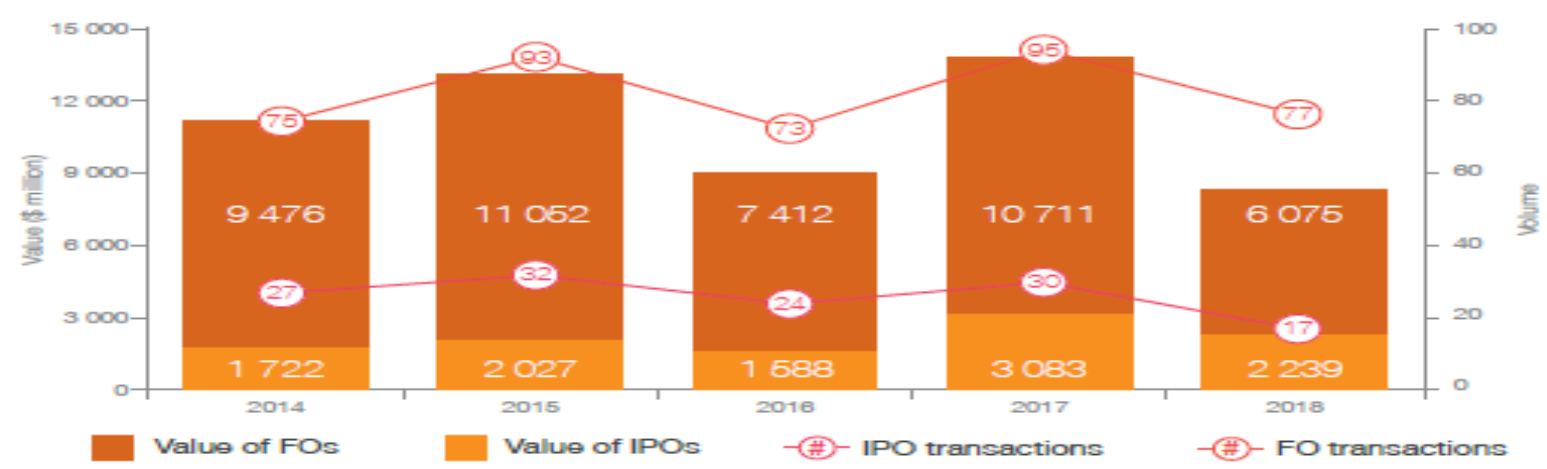

Source: Africa Capital Markets Report 2018

\section{Conclusion and Recommendations}

Enhancing African capital markets is one of the goals of the African Union Agenda 2063 for as the continent seeks to take full responsibility for financing its development. This paper explores trends and challenges in the development of African financial markets over the past two decades using a descriptive research model on key data from international think tanks to observe the behaviour of financial markets data in African countries. The study finds that African financial markets still face the traditional challenge of lack of market depth relative to other regions in other continents due to their limit size and very low market capitalisation to exploit expansion opportunities. This study makes the following recommendations as part of the solution to challenges faced by African financial markets. There are a number of initiatives that continental bodies like the African Union, its governance and development monitoring organs such as the African Peer Review Mechanism (APRM) can play to enhancing the development of financial markets on the continent. Efficient financial markets is also one of the indicators in the four thematic areas of APRM's assessment of good economic governance and financial management transparency for promoting economic growth and reducing poverty. As part of supporting the implementation of Agenda 2063, the APRM should support African countries to enhance their financial markets development through the following ways.

Improve Liquidity: There is a fundamental immediate need for African countries to improve liquidity of financial markets to attract more companies and securities to list on exchanges. Companies and securities are not listing on African exchanges due lack of capacity in the exchanges to raise the capital they need and the high exchange listing fees, legal fees and other costs of making company trading information accessible to all shareholders makes the listing exercise unviable. To overcome this African countries should remove or lower barriers to entry for small firms to expand the pipeline of new listed companies by introducing an alternative secondary market for small and medium-sized enterprises, which can act as an 'incubator' for small companies with low capitalisation before they list on the main board. In addition to removing barriers, exchanges should lower transaction costs to become more attractive vehicles for raising capital and new investment. The focus should be on increasing small and medium-sized enterprises to access financial markets through implementing policies that encourage financial market growth as a vital means of deepening markets.

Digitization: It is one of the elemental factors underpinning the future global economic growth as the world prepares for the $4^{\text {th }}$ Industrial Revolution (4IR). Enabling African countries to integrate into the global value chains by transforming economies through Science, Technology and Innovation (STI) is one of the goals in Agenda 2063. The use of digital technologies is changing a business models, providing new revenues and value-producing opportunities. The AU have to expand its system for supporting governments to be adopt new technology and building clear techniques that entail all of the advantages of a fourth commercial revolution. Following the trends in global financial markets, African governments should begin to invest in Block chain infrastructure (already implemented in the Australian and Canadian Exchanges) and support application of Distributed Ledger Technology (DLT) in financial markets trading (adopted by the Israel's Tel 
Aviv Exchange), replacing the traditional settlement systems (Accenture Wealth Management Strategists, 2018). Digitization of African financial markets should be a matter of national priority as billions of transactions are taking place every second in the current investment world and traditional financial markets are unable to cope with the quantities and speed.

Regional Integration: To complement the continent's efforts towards economic integration by establishing Continental Financial Institutions, integration of national and regional financial markets is key to accelerate continental economic convergence and integration through in the mobilisation of resources and management of the African financial sector. Economic convergence begins with integration of financial markets with other national and regional exchanges. For small, illiquid and inefficient national exchanges dominated by either sovereign bonds or a few listings such as the Douala Stock Exchange with 2 active counters, the Bolsa de Valores de Cabo Verde with 4 counters and the Algiers Stock Exchange with 5 active counters, these financial markets need to integrate with one another to improve capitalisation and liquidity.

Improve Legislative Environment: There is need to improve the regulatory environment and do away with excessive capital controls. Governments should also support financial markets by providing enabling environment and tax incentives to encourage more listing. African financial markets need to attract more foreign capital, hence legislation should support foreign investors to invest in African financial markets to increasing liquidity in exchanges. Well-functioning financial markets requires strong legal institutions and a sound legal framework, investor protection, legal enforcement laws and good corporate governance as an enabling business environment to support growth. Central banks should also be given the institutional independence to effectively administer monetary policy and maintain the value of a country's currency whilst managing inflation the band. The institutional strength of the central bank determines its ability to manage the demands of foreign investors, balancing the need for foreign currency and domestic currency.

Adoption and Implementation of International Standards: To counter the perception that African financial markets are non-transparent, adopting international standards and best practices will be a key step towards promoting transparency and accountability. Continental governance and monitoring organ of The African Union, the African Peer Review Mechanism (APRM) can be instrumental in supporting countries towards universal adoption and implement of key international standards for best practices such as Basel III international regulatory framework and International Financial Accounting Standards (IFRS) as a requirement for all companies. These will address most of the challenges faced by African markets such as thin trading, low turnover ratios and lack of liquidity as efficient trading and settlement infrastructure allows quick completion of transactions. This will promote coherence, consistency and quality of information provided in financial reports, its usefulness and reliance of such reports to users.

Introduce Financial Literacy and Education: The World Bank's, Global Findex database (2018), shows the percentage of adults between 24 and 60 years old that has owes a loan and required to pay it back with interest. The highest, South Africans (86 percent), Kenya (79 percent), Niger (71 percent) and Botswana (69 percent), compared to worldwide average of 40 percent. The database shows that one in every five Africans that have borrowed are in arrears as they lack financial literacy to quantify the real cost of credit compared to their capacity to repay the principal plus interest, which is usually very expensive. Financial markets present opportunities for venture capitalists to access relatively cheaper capital than they would from both banks and informal moneylender. With well-implemented financial education initiatives, Africa has the capacity to address financial disintermediation and illegal capital flow, which could double the current financial markets capitalisation. The APRM as it have the mandate from the African Union to track progress and implementation of Agenda 2063 and UN Sustainable Development Goals, can also report on the status of financial education programmes developed in Africa and make recommendations for policy makers.

\section{References}

Accenture Wealth Management Strategists, A. (2018). Capital markets vision 2022 manacapital markets vision 2022: Relevance, Value and Growth in the Digital Era, (Accessed 26 August 2019), Available on https://capitalmarketsblog.accenture.

Africa Capital Markets Report, P. (2017). Africa Capital Markets Watch. Africa Capital Markets Watch, 
Accessed 2(March).

Africa Financial Markets Initiative, A. (2018). Africa financial markets initiative annual conference theme: enhancing transparency in African bond markets, (October).

African Development Bank Group, (AfDB). (2018). African Statistical Yearbook.

African Securities Exchange Association, A. (2017). Annual Report. Forensic Science Regulator, (January), 46.

Bank for International Settlements. (2017). 87th Annual Report. BIS Annual Economic Report.

Bernhard, W. \& Leblang, D. (2006). Democratic processes and financial markets: Pricing politics. Cambridge University Press.

Centre for Affordable Housing Finance in Africa (CAHFA). (2017). Residential reits and their potential to increase investment in and access to affordable housing in Africa main report, (February).

Demirguc-Kunt, A., Klapper, L., Singer, D., Ansar, S. \& Hess, J. (2018). The Global Findex Database 2017: Measuring Financial Inclusion and the Fintech Revolution. The Global Findex Database 2017: Measuring Financial Inclusion and the Fintech Revolution.

Desjardins, J. (2016). All of the World's Stock Exchanges by Size. The Money Project.

Evans, A. (2019). Overcoming the global despondency trap: strengthening corporate accountability in supply chains. Review of International Political Economy, 2(1), 1-28.

Fama, E. F. (1976). Efficient capital markets: reply. The Journal of Finance, 31(1), 143-145.

Ferrara, F. M. \& Sattler, T. (2018). The Political Economy of Financial Markets.

Global Standards Proportionally Working Group Survey Report. (2019). Survey report on the implementation of the Basel framework, Available at: https://www.afi-global.org/sites/def.

Governance Across Borders. (2015). Why should Africa adopt IFRSs? Adoption is less of the story.. not practicing what you preach is the bigger evil. January 11, 2012.

Hrnjic, E., Reeb, D. M. \& Yeung, B. (2019). Financial Decisions, Behavioral Biases, and Governance in Emerging Markets. In The Oxford Handbook of Management in Emerging Markets, 161.

In On Africa (IOA). (2017). Africa Country Benchmark Report.

International Centre for Tax \& Development (ICTD). (2019). Taxing Africa: Coercion, Reform and Development Abstract : International Centre for Tax \& Development (ICTD).

International Financial Reporting Standards (IFRS). (2019). Who uses IFRS Standards? International Financial Reporting Standards, Accessed 1.

International Monetary Fund, I. (2018). Exchange Rate Regimes in Sub-Saharan Africa: Experiences and Lessons. Regional Economic Outlook: Sub-Saharan Africa, 32, 31-60.

Ivashina, V. \& Lerner, J. (2019). Patient Capital: The Challenges and Promises of Long-Term Investing. Princeton University Press, New York.

Karlsson, C. \& Tavassoli, S. (2019). Policy evaluation in competitiveness: towards more results-oriented industrial policies: Smart, Sustainable and Inclusive Growth. Edward Elgar Publishing, Northampton.

London Stock Exchange. (2019). Fees for companies and nominated advisers, (April).

Matewos, K. R., Navkiranjit, K. D. \& Jasmindeep, K. (2016). Financial literacy for developing countries in Africa: A review of concept, significance and research opportunities. Journal of African Studies and Development, 8(1), 1-12.

Messy, F. A. \& Monticone, C. (2012). The Status of Financial Education in Africa OECD working papers on finance, insurance and private pensions. OECD Development Policy Papers, (No. 25).

Mutize, M. \& Gossel S. J. (2017). Corrupt state owned enterprises lie at the heart of South Africa's economic woes.

Newell, G. D. (2019). Capital Flow Dynamics: Theory and Evidence. PhD Thesis and Florida State University, Tallahassee.

OECD. (2015). New Approaches to SME and Entrepreneurship Financing: Broadening the Range of Instruments. Oecd, 119.

Official Monetary and Financial Institutions Forum. (2017). Africa Financial Markets Index, 1-35.

Organisation for Economic Co-operation and Development, O. (2018). Development aid at a glance statistics by region. Official Development Assistance.

Price Water Cooper, P. (2018). Africa Capital Markets Watch 2018, (February 2017), 26.

Standard Bank Stockbrokers. (2019). Fees and costs: Online trading, 123-134.

United Nations Conference on Trade and Development (UNCTAD). (2018). World Investment Report.

World Economic Forum, 2018. (2018). The Global Competitiveness Report 2018. 


\section{Appendix}

Table 1: Africa's Stock Markets Capitalisation

\begin{tabular}{|c|c|c|c|c|c|c|}
\hline Economy & Exchange & Code & $\begin{array}{l}\text { Founde } \\
\text { d }\end{array}$ & $\begin{array}{l}\text { No. of } \\
\text { Listing } \\
\text { S }\end{array}$ & $\begin{array}{l}2017 \\
\text { Capitalisatio } \\
\text { n } \\
\text { (US\$ } \\
\text { Billions) }\end{array}$ & $\begin{array}{l}2018 \\
\text { Capitalisatio } \\
\text { n } \\
\text { (US\$ } \\
\text { Billions) }\end{array}$ \\
\hline Algeria & Algiers Stock Exchange & SGBV & 1997 & 5 & 0.147 & - \\
\hline Botswana & Botswana Stock Exchange & BSE & 1989 & 44 & 4.78 & 4.4 \\
\hline Cameroon & Douala Stock Exchange & DSX & 2001 & 2 & 0.28 & 0.3 \\
\hline Cape Verde & Bolsa de Valores de Cabo Verde & BVC & 2005 & 4 & 0.089 & 0.081 \\
\hline Benin & \multirow{7}{*}{$\begin{array}{l}\text { Bourse Régionale des Valeurs } \\
\text { Mobilières }\end{array}$} & \multirow{7}{*}{ BRVM } & \multirow{7}{*}{1998} & \multirow{7}{*}{44} & \multirow{7}{*}{10.5} & \multirow{7}{*}{11.7} \\
\hline Burkina Faso & & & & & & \\
\hline $\begin{array}{l}\text { Côte d'Ivoire } \\
\text { Guinea }\end{array}$ & & & & & & \\
\hline Bissau & & & & & & \\
\hline Mali & & & & & & \\
\hline Niger & & & & & & \\
\hline $\begin{array}{l}\text { Senegal } \\
\text { Togo }\end{array}$ & & & & & & \\
\hline Egypt & Egyptian Exchange & EGX & 1883 & 247 & 61.5 & 70.03 \\
\hline Ghana & Ghana Stock Exchange & GSE & 1990 & 43 & 29.4 & 20.11 \\
\hline Kenya & Nairobi Securities Exchange & NSE & 1954 & 65 & 20.6 & 25.57 \\
\hline Libya & Libyan Stock Market & LSM & 2007 & 7 & 3.04 & - \\
\hline Malawi & Malawi Stock Exchange & MSE & 1995 & 14 & 13 & 15.74 \\
\hline Mauritius & Stock Exchange of Mauritius & $\begin{array}{l}\text { SEM } \\
\text { Casa }\end{array}$ & 1988 & 95 & 8.5 & 8.66 \\
\hline $\begin{array}{l}\text { Morocco } \\
\text { Mozambiqu }\end{array}$ & Casablanca Stock Exchange & SE & 1929 & 81 & 54.8 & 53.44 \\
\hline $\mathrm{e}$ & Bolsa de Valores de Mozambique & BVM & 1999 & 3 & 1 & - \\
\hline Namibia & Namibia Stock Exchange & NSX & 1992 & 40 & 136.9 & 148.48 \\
\hline Nigeria & Nigerian Stock Exchange & NSE & 1960 & 223 & 114.2 & 116.4 \\
\hline Rwanda & $\begin{array}{l}\text { Rwanda Stock Exchange } \\
\text { Seychelles Securities Exchange (Trop- }\end{array}$ & RSE & 2008 & 8 & 1.9 & 1.93 \\
\hline Seychelles & $\mathrm{X})$ & SSE & 2012 & 4 & 0.011 & 0.033 \\
\hline Sierra Leone & Sierra Leone Stock Exchange & & 2009 & 3 & & \\
\hline Somalia & Somalia Stock Exchange & & 2012 & - & - & - \\
\hline South Africa & Johannesburg Stock Exchange & JSE & 1887 & 402 & 970.5 & 1150.5 \\
\hline Sudan & Khartoum Stock Exchange & KSE & 1994 & 54 & 1.8 & 2.1 \\
\hline Swaziland & Swaziland Stock Exchange & SSX & 1990 & 10 & - & - \\
\hline Tanzania & Dar es Salaam Stock Exchange & DSE & 1998 & 17 & 10.46 & 12.8 \\
\hline Tunisia & Bourse de Tunis & BVMT & 1969 & 56 & 8.6 & 9.32 \\
\hline Uganda & Uganda Securities Exchange & USE & 1997 & 17 & 8.3 & 9.49 \\
\hline Zambia & Lusaka Stock Exchange & LuSE & 1994 & 23 & 10.2 & - \\
\hline Zimbabwe & Zimbabwe Stock Exchange & ZSE & 1948 & 64 & 5.4 & 4.33 \\
\hline
\end{tabular}

Source: ASEA Annual report (2017) 